\title{
ENDOCRINE AND METABOLIC EFFECTS OF ADIPOSE TISSUE IN CHILDREN AND ADOLESCENTS ENDOKRINA IN PRESNOVNA FUNKCIJA MAŠČOBNEGA TKIVA PRI OTROCIH IN MLADOSTNIKIH
}

\author{
Primož KOTNIK ${ }^{1,2, *}$, Pamela FISCHER POSOVSZKY ${ }^{3}$, Martin WABITSCH ${ }^{3}$ \\ 'University Medical Centre Ljubljana, University Children's Hospital, Department of Pediatric Endocrinology, \\ Diabetes and Metabolic Diseases, Bohoriceva 20, 1000 Ljubljana, Slovenia \\ ${ }^{2}$ University of Ljubljana, Faculty of Medicine, Vrazov trg 2, 1000 Ljubljana, Slovenia \\ 3Universitätsklinikum Ulm, Eythstr. 24, 89070 Ulm, Germany
}

\section{ABSTRACT}

Keywords:

adipose tissue, obesity, endocrinology, adipokine, metabolic syndrome, child
Adipose tissue is implicated in many endocrine and metabolic processes. Leptin was among the first identified adipose-secreted factors, which act in an auto-, para- and endocrine manner. Since leptin, many other adipose tissue factors were determined, some primarily secreted from the adipocytes, some from other cells of the adipose tissue.

So-called adipokines are not only involved in obesity and its complications, as are insulin resistance, type 2 diabetes and other components of the metabolic syndrome, but also in growth, reproduction, bone metabolism, immune response, cancer development and many other important biological processes. Research in the field of adipokines has revealed new insights into the physiological and pathophysiologal processes and opened new therapeutic possibilities. In the present article, a special emphasis is devoted to research in children and adolescents.

\section{IZVLEČEK}

Ključne besede:

maščobno

tkivo, debelost, endokrinologija, adipokini, metabolni sindrom, otroci
Maščobno tkivo ima vlogo pri številnih endokrinih in presnovnih procesih. Lepin je bil med prvimi odkritimi dejavniki iz maščobnega tkiva, ki delujejo avto-, para- in endokrino. Od opredelitve leptina so odkrili še številne druge dejavnike, od katerih se nekateri izločajo iz maščobnih celic, nekateri pa iz drugih celic maščobnega tkiva.

Tako imenovani adipokini niso povezani le z debelostjo in njenimi zapleti, kot so rezistenca proti inzulinu, sladkorna bolezen tipa 2 in druge komponente metabolnega sindroma, temveč tudi z rastjo, razmnoževanjem, presnovo kosti, imunskim odzivom, razvojem rakavih bolezni in mnogimi drugimi pomembnimi biološkimi procesi. Raziskave na področju adipokinov so opredelile nove fiziološke in patofiziološke procese in odprle nove možnosti zdravljenja. $V$ tem prispevku poseben poudarek namenjamo raziskavam pri otrocih in mladostnikih. 


\section{BACKGROUND}

Adipose tissue was long considered to be an energy storage tissue only. Adipocytes store energy in the form of triglycerides when there is an excess of energy, and release it when energy is needed. By studying genetically obese and diabetic mice (ob/ob, db/db), it was determined that factors released from adipocytes are able to communicate with distant tissues and influence their function. Leptin was the first cytokine with such function to be determined. Since leptin, several additional factors with endocrine functions were determined. Some - as leptin and adiponectin - are released from the fat cells exclusively, whilst others are also released from others cells of the adipose tissue (macrophages, fibrocytes, endothelial cell), and other organs (liver, bone) $(1,2)$.

In the manuscript, we will discuss the role of the selected adipokines in obesity, and the development of components of metabolic syndrome, with an emphasis on their role in children and adolescents.

\section{LEPTIN}

The discovery of leptin caused a paradigm shift in the way adipose tissue is perceived. It is no longer regarded as an energy storage organ only, but also as an important endocrine organ with important effects on body metabolism. Leptin levels are increased in adipose tissue and circulation in human obese subjects, including children and adolescents (3-5). Mutations in the leptin gene or its receptor are associated with human morbid and early obesity $(2,6)$. Its levels are correlated with body mass index (BMI) and fat store content. They are decreased in subjects with decreased fat mass, such as lipodystrophy and anorexia $(7,8)$. Following weight loss, leptin levels decrease in both adults and children $(9,10)$. Leptin levels are higher in subcutaneous that visceral adipose tissue. They are higher in females as compared to males, and this dimorphism is present already in children (5). A mechanism described behind this dimorphism is the suppressive effect of androgens on leptin expression in adipocytes (11).

Central nervous system (CNS) leptin effects - particularly at the level of hypothalamus - are associated with energy homeostasis. Following secretion of leptin from fat stores into circulation, it is transported across the blood-brain barrier to CNS, where it stimulates processes that result in decreased food intake and increased energy consumption. In common obesity leptin resistance at the level of CNS, is a mechanism explaining continued energy intake despite severely increased circulating leptin levels (12).

In addition to CNS, leptin receptors are also present in peripheral tissues, where leptin decreases fat stores in the skeletal muscle and liver by stimulating fatty acid oxidation and glucose uptake. Peripheral leptin resistance (particularly in skeletal muscle) is also linked to insulin resistance (IR) in obesity $(13,14)$, and to the development of nonalcoholic fatty liver disease and metabolic syndrome in children $(15,16)$.

Besides its effects on energy homeostasis, leptin has several other important endocrine functions. The lack of leptins action at the level of CNS, is also associated with reduced reproductive function (6). Leptin is implicated in the regulation of immunologic and inflammatory processes (17). At the level of the bone, leptin has a dual and opposing role. On one hand, it stimulates osteoblasts, bone mineralization and growth, while, on the other hand, it suppresses bone development $(18,19)$. It has also been implicated in tumorigenesis, as leptin receptors can be found in certain cancer cells, possibly enabling leptin to stimulate growth of these cells under certain conditions (20).

Leptin has been successfully used in the therapy of leptin deficient subjects ameliorating hyperphagia, extreme obesity, hypogonadism and impaired cell immunity (6). Leptin is able to induce puberty in hypogonadotropic hypogonadism due to leptin deficiency, and to reduce liver steatosis associated with obesity due to leptin-deficiency $(21,22)$. In polygenic obesity, leptin therapy was not as successful, probably due to leptin resistance being the main feature in this condition (12). It could, however, be potentially used in subjects following weight loss. In these subjects, a decrease in fat content leads to decreased leptin levels and decreased energy expenditure, possibly preventing further weight loss or enabling a regain of lost weight. By administration of leptin at this stage, one could prevent a regain of weight in these subjects (23). In addition, leptin mimetics have been proposed to overcome leptin resistance, and co-administration of amylin with leptin was shown to positively modify leptin signalling (24).

\section{ADIPONECTIN}

Adiponectin is expressed in the mature adipocyte and is secreted into blood circulation, where it is present in 3 main oligomeric forms, high molecular weight (HMW) form being linked with most of the effects on peripheral tissues (25).

In contrast to leptin, and indeed most of the other adipokines, adiponectin blood levels are not increased, but decreased in obesity, including in children (26). There is a strong negative correlation between plasma adiponectin levels with body fat mass (27). Following weight loss, adiponectin levels increase in both adults and children $(26,28)$. The anti-obesity effect is associated 
with the ability of adiponectin to increase body's energy expenditure and to decrease differentiation of adipocytes in experimental animals (29).

Adiponectin is, similarly to leptin, secreted in a gender dimorphic fashion, with circulating levels being higher in women than in men. Although stimulation of adipocytes with human male serum leads to a decrease in the expression of adiponectin, increasing concentrations of testosterone or estradiol do not influence either adiponectin mRNA expression or secretion, implicating, to date, unidentified serum gender specific factors (30).

In the peripheral tissues, adiponectin's actions are mediated through adiponectin receptor 1 or 2 (AdipoR1, AdipoR2). In skeletal muscles, adiponectin acts mainly through AdipoR1 and through AdipoR2 in the liver. Variations in the expression levels of these receptors at the level of the peripheral tissues, are in addition to circulating levels associated with adiponectin's effects (31).

Adiponectin acts as an insulin sensitizer in both experimental animals and humans. Insulin sensitising mechanism is linked to a reduction of hepatic gluconeogenesis and an increase of muscle glucose transport (32). Low levels of adiponectin, especially HMW form, are associated with the development of IR, type 2 diabetes (T2D), components of the metabolic syndrome and cardiovascular disease (33-35). This link is also present in children and adolescents $(36,37)$. Certain single nucleotide polymorphisms (SNP) in the adiponectin gene are associated with low adiponectin levels and T2D $(38,39)$. On the other hand, increased adiponectin levels are associated with the reduced risk of T2D (40), and therapy with insulin sensitizing drugs thiazolidinediones increases adiponectin (primarily HMW) levels (41). In children, lifestyle modifications also result in a beneficial increase in adiponectin levels, accompanied by increased insulin sensitivity (26).

Adiponectin has also anti-inflammatory and anti-oxidant properties. It inhibits tumor necrosis factor (TNF), alpha and superoxide radical generation in endothelial cells, and TNFalpha generation in adipose tissue (42). Low levels of adiponectin are also associated with nonalcoholic steatohepatitis independent of IR (43). In addition, low levels of adiponectin are linked to an increased risk of malignancies (44).

\section{VISFATIN}

Previously known as pre-B cell colony enhancing factor, visfatin is a controversial adipokine, whose levels were shown to be either increased, normal or decreased in adult human obesity (45-48). In children and adolescents, circulating visfatin levels and SNPs in visfatin gene were also inconsistently linked to obesity determined by
BMI or waist circumference (49-51). Furthermore, it is controversial whether visfatin is predominantly expressed in human visceral or subcutaneous adipose tissue $(45,52$, 53).

Visfatin binds to insulin receptor and was suggested to have insulin-like effects (52). It was determined to be a nicotinamide phosphoribosyltransferase implicated in promoting insulin secretion upon glucose stimulation $(54,55)$. Circulating visfatin levels are increased by hyperglycaemia in mouse models of T2D and in humans with type 1 diabetes (T1D) and T2D (52, 56). Again, these results were not confirmed in all studies, and SNPs in visfatin gene are not linked to T2D (54). In obese children, visfatin levels do not differ between those with and without IR (51). On the other hand, in children visfatin gene, SNPs are linked to higher visfatin levels, components of metabolic syndrome and low grade inflammation (51).

A decrease in body weight - following bariatric surgery and exercise in T1D subjects lowers visfatin levels (47, 57). Treatment with insulin sensitizing drug rosiglitazone in humans does not lower visfatin levels (58).

Visfatin is implicated in the pathogenesis of chronic conditions, as are atherosclerosis and cardiovascular diseases (59). It is suggested to be a proinflammatory cytokine. As obesity is a state of chronic low-grade inflammation, this could be the common mechanism explaining some of the reported results; still, visfatin's role in obesity and its complications need to be further addressed.

\section{RESISTIN}

Although resistin is also expressed in adipocytes, the main source of resistin in humans are macrophages (60). Structurally, resistin is very similar to adiponectin including the formation of higher-order oligomerisation structures. In contrast to adiponectin, however, lowmolecular structures are more physiologically active (61). Increased resistin levels were determined in human obesity in both adults and children, and a SNP in the resistin promoter is associated with obesity (62-65). More specifically, circulating levels of resistin were, in particular, associated with body fat mass in children (66). In animal obesity models, increased resistin levels are linked to IR, and resistin was described as a possible link between obesity and the development of T2D (67). Decreasing resistin levels or blocking its action, is linked to improved insulin sensitivity and glucose metabolism $(67,68)$. In humans, controversial results on the role of resistin in the development of IR, T2D and metabolic syndrome are described $(63,64,69)$. Increased circulating levels are also reported in T1D subjects (70). A SNP in resistin promoter is, in addition to obesity, also associated with T2D (71). 
Resistin is also linked with states of inflammation including low-grade inflammation in obesity $(72,73)$. Similarly as for visfatin, resistin's role in the development of obesity and its complications needs to be further addressed.

\section{RETINOL BINDING PROTEIN 4 (RBP4)}

Increased circulating and adipose tissue RBP4 levels are linked to obesity and visceral fat mass content $(74,75)$. Several studies, however, found no correlation between circulating RBP4 levels, the level of obesity, and the amount and distribution of adipose tissue (76-78).

RBP4 is suggested to be involved in early processes of atherosclerosis and cardiovascular diseases (79, 80). Circulating and adipose tissue RBP4 levels are associated with IR and T2D in both adults and in children and adolescents (81-83). RBP4 levels also correlate with other components of the metabolic syndrome (84-86). They decrease with lifestyle interventions - reduction of weight, increased exercise - in adults, children and adolescents (76, 87, 88). The associations between RBP4 levels and the development of obesity and its complications, such as IR, impaired glucose tolerance, T2D and certain components of the metabolic syndrome, have, however, not been found consistently in both adults and children $(77,78,89-92)$.

Obesity is a state of low-grade inflammation. Several adipokines have been shown to be regulated by inflammatory factors (93). We therefore studied RBP4 expression in human adipocytes exposed to inflammatory milieu (culture media from activated machrophages), or selected proinflammatory cytokines interleukin 1 beta (IL-1beta) and TNFalpha, and determined that RBP4 expression in adipose tissue was consistently decreased in a proinflammatory environment (94). These results link inflammation and altered expression of RBP4 in adipose tissue, even though it seems that changes in RBP4 expression in adipose tissue are not directly related to the changes in circulating RBP4 levels that often precede the development of systemic IR $(94,95)$.

The levels of circulating RBP4 seem to be regulated in a sex-dependent manner. Males, including adolescents, showed higher levels of RBP4 compared to females (78, 96-99). Also, women with increased androgen levels had in increase in circulating RBP4 (78, 96-99). This sexual dimorphism was, however, not demonstrated in all studies (75, 100-102). Two classic adipokines, leptin and adiponectin, are regulated in a sex-dependent manner. In contrast to RBP4, their levels are lower in males compared to females, and further studies demonstrated that the male sex hormone testosterone inhibited the expression of leptin and adiponectin in adipocytes $(11,103)$.

We therefore decided to further explore the gender specific regulation of RBP4 expression in human adipocytes. As a model system, we used the human Simpson-Golabi-Behmel syndrome (SGBS) cell strain. These cells are characterized by a high capacity for adipogenic differentiation, and therefore provide a suitable cell system to study human adipocyte biology (104).

Effects of gender specific serum factors on RBP4 expression in human SGBS adipocytes were investigated. We collected serum samples from 10 healthy non-obese females (estradiol $89.99 \mathrm{pg} / \mathrm{ml}$, testosteron $0.37 \mathrm{ng} /$ $\mathrm{ml}$, leptin $16.0 \mathrm{ng} / \mathrm{ml}$ ) and 10 healthy non-obese males BMI- and age-matched volunteers (estradiol $34.58 \mathrm{pg} / \mathrm{ml}$, testosterone $4.18 \mathrm{ng} / \mathrm{ml}$, leptin $2.2 \mathrm{ng} / \mathrm{ml}$ ). After pooling these samples, we added them to adipocyte cultures at a concentration of $10 \%$ ( $\mathrm{vol} / \mathrm{vol})$. As a control experiment, we first studied the expression of adiponectin. As expected from earlier studies, male serum was more efficient in downregulating adiponectin mRNA than female serum (Figure 1A) (30). Likewise, both female and male serum suppressed RBP4 mRNA expression, with male serum showing a significantly stronger inhibitory effect than female serum (Figure 1B). These results are in accordance with the data obtained from male and female adipose tissue explants, where significantly higher mRNA expression was determined in female adipose tissue when compared to male (100).

A

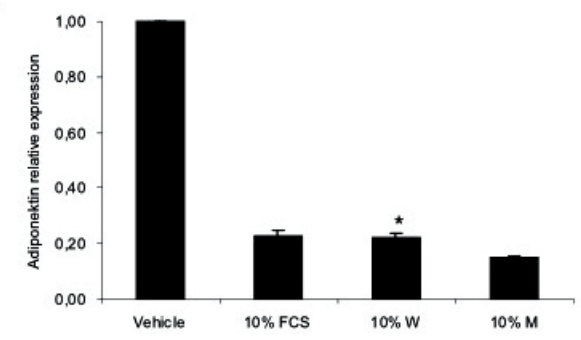

B

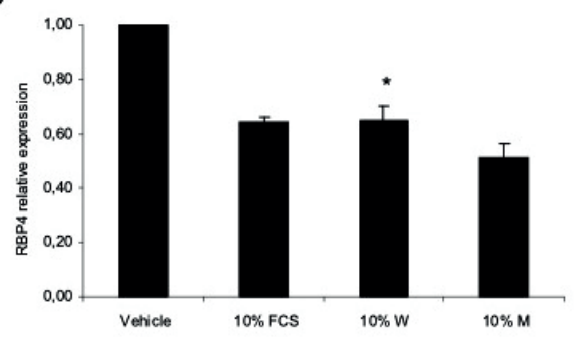

Figure 1A, 1B. Effects of pooled $10 \%$ female $(F)$ or male $(M)$ serum on adiponectin $(A)$ and retinol binding protein 4 (B) mRNA expression in SGBS adipocytes.

mRNA expression ratios were determined by qRT-PCR, using succinate dehydrogenase as a reference. Data are presented as mean \pm SEM of 3 or more independent experiments, and are normalized to the expression or secretion in the vehicle ( $1 \%$ ethanol) treated samples. ${ }^{*} p<0.05$ when compared to the vehicle. 


\section{CHEMERIN}

Adipose tissue and liver are the main sources of chemerin, a chemo-attractant protein that acts through chemokine like receptor 1 (CMKLR1), which is located to adipocytes, endothelial cells and inflammatory cells (e.g. dendritic cells and macrophages). Chemerin is implicated in the process of adipogenesis, and its higher levels are associated with obesity, especially visceral, in both adults and children $(105,106)$. Interestingly, higher levels were determined in vitamin $\mathrm{D}$ deficient obese children, compared to vitamin $\mathrm{D}$ non-deficient obese children (107). Dysregulation of chemerin is associated with several metabolic abnormalities, such as increased blood pressure and total cholesterol, decreased HDL cholesterol, prediabetic state of IR and T2D (105). Chemerin levels positively correlate with leptin and negatively with adiponektin levels (108). In children, higher levels are associated with low-grade inflammation and endothelium dysfunction, as determined by markers of endothelial activation intercellular adhesion molecule-1 (ICAM-1) and E-selectin (109).

\section{CONCLUSIONS}

Adipose tissue is regarded an important endocrine tissue. Dysregulation of factors secreted from the adipose tissue - so-called adipokines - is not linked only to obesity and its complications, but has also important effects on bone metabolism, reproduction, immunity, cancer development, etc.

Several adipokines are considered biomarkers of pathophysiological states, in particular those linked to obesity. Some are still considered controversial due to inconsistent experimental results, and will have to be further studied in larger and well-controlled studies. In the future, disease-specific arrays of adipokines will possibly be used to determine, with higher specify and sensitivity, those at a significant risk of selected disease, or they will be used as monitoring tools to evaluate the efficacy of treatment. Of importance, noninvasive methods that will enable us to determine the origin of studied adipokines (e.g. visceral vs. subcutaneous adipose tissue) will bring the role of adipokines, as biomarkers, to a new and a higher level.

In addition, it is possible that the manipulation of the expression or actions of selected adipokines will be used therapeutically in the future. To this effect, leptin was the first adipokine used therapeutically in states of leptin deficiency (e.g. congenital leptin deficiency or certain lypodystrophies). As adipokines have increasingly important endocrine and metabolic effect also in nonobesity associated states, it is probable that adipokine therapy will also be used in non-obesity relates states. Delivery of therapeutic adipokine to a specific tissue, possibly with the use of combination therapy, would be of special benefit.

\section{CONFLICTS OF INTEREST}

The authors declare that no conflicts of interest exist.

\section{FUNDING}

This study was supported by the Slovenian National Research Agency grants P3-0343, J3-6798 and J3-6804.

\section{ETHICAL APPROVAL}

Not required.

\section{REFERENCES}

1. Zhang Y, Proenca R, Maffei M, Barone M, Leopold L, Friedman JM. Positional cloning of the mouse obese gene and its human homologue. Nature 1994; 372: 425-32.

2. Chen H, Charlat O, Tartaglia LA, Woolf EA, Weng X, Ellis SJ. et al. Evidence that the diabetes gene encodes the leptin receptor: identification of a mutation in the leptin receptor gene in $\mathrm{db} / \mathrm{db}$ mice. Cell 1996; 84: 491-5.

3. Halaas JL, Gajiwala KS, Maffei M, Cohen SL, Chait BT, Rabinowitz D. et al. Weight-reducing effects of the plasma protein encoded by the obese gene. Science 1995; 269: 543-6.

4. Lonnqvist F, Arner P, Nordfors L, Schalling M. Overexpression of the obese (ob) gene in adipose tissue of human obese subjects. Nat Med 1995; 1: 950-3.

5. Caprio S, Tamborlane WV, Silver D, Robinson C, Leibel R, McCarthy $S$. et al. Hyperleptinemia: an early sign of juvenile obesity: relations to body fat depots and insulin concentrations. Am J Physiol 1996; 271: E626-30.

6. Farooqi IS, Matarese G, Lord GM, Keogh JM, Lawrence E, Agwu C. et al. Beneficial effects of leptin on obesity, T cell hyporesponsiveness, and neuroendocrine/metabolic dysfunction of human congenital leptin deficiency. J Clin Invest 2002; 110: 1093-103.

7. Fiorenza CG, Chou SH, Mantzoros CS. Lipodystrophy: pathophysiology and advances in treatment. Nat Rev Endocrinol 2011; 7: 137-50.

8. Hebebrand J, Muller TD, Holtkamp K, Herpertz-Dahlmann B. The role of leptin in anorexia nervosa: clinical implications. Mol Psychiatry 2007; 12: 23-35.

9. Considine RV, Sinha MK, Heiman ML, Kriauciunas A, Stephens TW, Nyce MR. et al. Serum immunoreactive-leptin concentrations in normal-weight and obese humans. N Engl J Med 1996; 334: 292-5.

10. Holm JC, Gamborg M, Kaas-Ibsen K, Gammeltoft S, Ward L, Heitmann $B L$. et al. Time course and determinants of leptin decline during weight loss in obese boys and girls. Int J Pediatr Obes 2007; 2: 2-10.

11. Wabitsch M, Blum WF, Muche R, Braun M, Hube F, Rascher W. et al. Contribution of androgens to the gender difference in leptin production in obese children and adolescents. J Clin Invest 1997; 100: 808-13.

12. Heymsfield SB, Greenberg AS, Fujioka K, Dixon RM, Kushner R, Hunt T. et al. Recombinant leptin for weight loss in obese and lean adults: a randomized, controlled, dose-escalation trial. JAMA 1999; 282: 1568-75. 
13. Steinberg GR, Parolin ML, Heigenhauser GJ, Dyck DJ. Leptin increases FA oxidation in lean but not obese human skeletal muscle: evidence of peripheral leptin resistance. Am J Physiol Endocrinol Metab 2002; 283: E187-92.

14. Steinberg GR, Smith AC, Van Denderen BJ, Chen Z, Murthy S, Campbell DJ. et al. AMP-activated protein kinase is not down-regulated in human skeletal muscle of obese females. J Clin Endocrinol Metab 2004; 89: 4575-80.

15. Yoshinaga M, Sameshima K, Tanaka Y, Wada A, Hashiguchi J, Tahara $\mathrm{H}$. et al. Adipokines and the prediction of the accumulation of cardiovascular risk factors or the presence of metabolic syndrome in elementary school children. Circ J 2008; 72: 1874-8.

16. Kim IK, Kim J, Kang JH, Song J. Serum leptin as a predictor of fatty liver in 7-year-old Korean children. Ann Nutr Metab 2008; 53: 109-16.

17. Fantuzzi G. Three questions about leptin and immunity. Brain Behav Immun 2009; 23: 405-10.

18. Reseland JE, Gordeladze JO. Role of leptin in bone growth: central player or peripheral supporter? FEBS Lett 2002; 528: 40-2.

19. Ducy $P$, Amling $M$, Takeda S, Priemel M, Schilling AF, Beil FT. et al. Leptin inhibits bone formation through a hypothalamic relay: a central control of bone mass. Cell 2000; 100: 197-207.

20. Lang K, Ratke J. Leptin and adiponectin: new players in the field of tumor cell and leukocyte migration. Cell Commun Signal 2009; 7: 27.

21. von SJ, Moss A, Nagel SA. et al. Leptin substitution results in the induction of menstrual cycles in an adolescent with leptin deficiency and hypogonadotropic hypogonadism. Horm Res Paediatr 2012; 77: 127-33.

22. von SJ, Moss A, Nagel SA, Muehleder H, Debatin KM, Farooqi IS. et al. Leptin substitution results in the induction of menstrual cycles in an adolescent with leptin deficiency and hypogonadotropic hypogonadism. Horm Res Paediatr 2012; 77: 127-33.

23. Rosenbaum M, Goldsmith R, Bloomfield D, Magnano A, Weimer L, Heymsfield $S$. et al. Low-dose leptin reverses skeletal muscle, autonomic, and neuroendocrine adaptations to maintenance of reduced weight. J Clin Invest 2005; 115: 3579-86.

24. Misra M. Obesity pharmacotherapy: current perspectives and future directions. Curr Cardiol Rev 2013; 9: 33-54.

25. Retnakaran R, Youn BS, Liu Y, Hanley AJ, Lee NS, Park JW. et al. Correlation of circulating full-length visfatin (PBEF/NAMPT) with metabolic parameters in subjects with and without diabetes: a cross-sectional study. Clin Endocrinol (Oxf) 2008; 69: 885-93.

26. Cambuli VM, Musiu MC, Incani M, Paderi M, Serpe R, Marras V. et al. Assessment of adiponectin and leptin as biomarkers of positive metabolic outcomes after lifestyle intervention in overweight and obese children. J Clin Endocrinol Metab 2008; 93: 3051-7.

27. Hu E, Liang P, Spiegelman BM. AdipoQ is a novel adipose-specific gene dysregulated in obesity. J Biol Chem 1996; 271: 10697-703.

28. Matsubara M, Maruoka S, Katayose S. Inverse relationship between plasma adiponectin and leptin concentrations in normal-weight and obese women. Eur J Endocrinol 2002; 147: 173-80.

29. Bauche IB, El Mkadem SA, Pottier AM, Senou M, Many MC, Rezsohazy R. et al. Overexpression of adiponectin targeted to adipose tissue in transgenic mice: impaired adipocyte differentiation. Endocrinology 2007; 148: 1539-49.

30. Horenburg S, Fischer-Posovszky P, Debatin KM, Wabitsch M. Influence of sex hormones on adiponectin expression in human adipocytes. Horm Metab Res 2008; 40: 779-86.

31. Yamauchi T, Kamon J, Ito Y, Tsuchida A, Yokomizo T, Kita S. et al. Cloning of adiponectin receptors that mediate antidiabetic metabolic effects. Nature 2003; 423: 762-9.

32. Kadowaki T, Yamauchi T, Kubota N, Hara K, Ueki K, Tobe K. Adiponectin and adiponectin receptors in insulin resistance, diabetes, and the metabolic syndrome. J Clin Invest 2006; 116: 1784-92.

33. Spranger J, Kroke A, Mohlig M, Bergmann MM, Ristow M, Boeing $\mathrm{H}$. et al. Adiponectin and protection against type 2 diabetes mellitus. Lancet 2003; 361: 226-8.
34. Nakashima R, Kamei N, Yamane K, Nakanishi S, Nakashima A, Kohno $N$. Decreased total and high molecular weight adiponectin are independent risk factors for the development of type 2 diabetes in Japanese-Americans. J Clin Endocrinol Metab 2006; 91: 3873-7.

35. Fisher FM, Trujillo ME, Hanif W, Barnett AH, McTernan PG, Scherer PE. et al. Serum high molecular weight complex of adiponectin correlates better with glucose tolerance than total serum adiponectin in IndoAsian males. Diabetologia 2005; 48:1084-7.

36. Panagopoulou P, Galli-Tsinopoulou A, Fleva A, Pavlitou-Tsiontsi E, Vavatsi-Christaki N, Nousia-Arvanitakis S. Adiponectin and insulin resistance in childhood obesity. J Pediatr Gastroenterol Nutr 2008; 47: 356-62.

37. Murphy MJ, Hosking J, Metcalf BS, Voss LD, Jeffery AN, Sattar N. et al. Distribution of adiponectin, leptin, and metabolic correlates of insulin resistance: a longitudinal study in British children; 1 : prepuberty (EarlyBird 15). Clin Chem 2008; 54: 1298-306.

38. Hara K, Boutin P, Mori Y, Tobe K, Dina C, Yasuda K. et al. Genetic variation in the gene encoding adiponectin is associated with an increased risk of type 2 diabetes in the Japanese population. Diabetes 2002; 51: 536-40.

39. Poitou C, Lacorte JM, Coupaye M, Bertrais S, Bedel JF, Lafon N. et al. Relationship between single nucleotide polymorphisms in leptin, IL6 and adiponectin genes and their circulating product in morbidly obese subjects before and after gastric banding surgery. Obes Surg 2005; 15: 11-23.

40. Lindsay RS, Funahashi T, Hanson RL, Matsuzawa Y, Tanaka S, Tataranni PA. et al. Adiponectin and development of type 2 diabetes in the Pima Indian population. Lancet 2002; 360: 57-8.

41. Kubota N, Terauchi Y, Kubota T, Kumagai H, Itoh S, Satoh H. et al. Pioglitazone ameliorates insulin resistance and diabetes by both adiponectin-dependent and -independent pathways. J Biol Chem 2006; 281: 8748-55.

42. Motoshima H, Wu X, Mahadev K, Goldstein BJ. Adiponectin suppresses proliferation and superoxide generation and enhances eNOS activity in endothelial cells treated with oxidized LDL. Biochem Biophys Res Commun 2004; 315: 264-71.

43. Hui JM, Hodge A, Farrell GC, Kench JG, Kriketos A, George J. Beyond insulin resistance in NASH: TNF-alpha or adiponectin? Hepatology 2004; 40: 46-54.

44. Kelesidis I, Kelesidis T, Mantzoros CS. Adiponectin and cancer: a systematic review. Br J Cancer 2006; 94: 1221-5.

45. Berndt J, Kloting N, Kralisch S, Kovacs P, Fasshauer M, Schon MR. et al. Plasma visfatin concentrations and fat depot-specific mRNA expression in humans. Diabetes 2005; 54: 2911-6.

46. Pagano C, Pilon C, Olivieri M, Mason P, Fabris R, Serra R. et al. Reduced plasma visfatin/pre-B cell colony-enhancing factor in obesity is not related to insulin resistance in humans. J Clin Endocrinol Metab 2006; 91: 3165-70.

47. Haider DG, Holzer G, Schaller G, Weghuber D, Widhalm K, Wagner O. et al. The adipokine visfatin is markedly elevated in obese children. J Pediatr Gastroenterol Nutr 2006; 43: 548-9.

48. Jin H, Jiang B, Tang J, Lu W, Wang W, Zhou L. et al. Serum visfatin concentrations in obese adolescents and its correlation with age and high-density lipoprotein cholesterol. Diabetes Res Clin Pract 2008; 79: 412-8.

49. Belo VA, Souza-Costa DC, Lacchini R, Sertório JT, Lanna CM, Carmo VP. et al. Adiponectin associates positively with nitrite levels in children and adolescents. Int J Obes (Lond) 2013; 37: 740-3.

50. Li RZ, Ma X, Hu XF, Kang SX, Chen SK, Cianflone K. et al. Elevated visfatin levels in obese children are related to proinflammatory factors. J Pediatr Endocrinol Metab 2013; 26: 111-8.

51. Taskesen D, Kirel B, Us T. Serum visfatin levels, adiposity and glucose metabolism in obese adolescents. J Clin Res Pediatr Endocrinol 2012; 4: 76-81. 
52. Fukuhara A, Matsuda M, Nishizawa M, Segawa K, Tanaka M, Kishimoto $K$. et al. Visfatin: a protein secreted by visceral fat that mimics the effects of insulin. Science 2005; 307: 426-30.

53. Varma V, Yao-Borengasser A, Rasouli N, Bodles AM, Phanavanh B, Lee MJ. et al. Human visfatin expression: relationship to insulin sensitivity, intramyocellular lipids, and inflammation. J Clin Endocrinol Metab 2007; 92: 666-72.

54. Revollo JR, Korner A, Mills KF, Satoh A, Wang T, Garten A. et al. Nampt/PBEF/ Visfatin regulates insulin secretion in beta cells as a systemic NAD biosynthetic enzyme. Cell Metab 2007; 6: 363-75.

55. Spinnler R, Gorski T, Stolz K, Schuster S, Garten A, Beck-Sickinger AG. et al. The adipocytokine Nampt and its product NMN have no effect on beta-cell survival but potentiate glucose stimulated insulin secretion. PLoS One 2013; 8: e54106.

56. Haider DG, Schaller G, Kapiotis S, Maier C, Luger A, Wolzt M. The release of the adipocytokine visfatin is regulated by glucose and insulin. Diabetologia 2006; 49: 1909-14.

57. Haider DG, Schindler K, Schaller G, Prager G, Wolzt M, Ludvik B. Increased plasma visfatin concentrations in morbidly obese subjects are reduced after gastric banding. J Clin Endocrinol Metab 2006; 91: 1578-81.

58. Pfutzner A, Marx N, Walcher D, Lobig M, Seidel D, Forst T. Impact of rosiglitazone on visfatin and adiponectin plasma concentrations in patients with type 2 diabetes and coronary artery disease. Clin Lab 2008; 54: 237-41.

59. Friebe D, Neef M, Kratzsch J, Erbs S, Dittrich K, Garten A. et al. Leucocytes are a major source of circulating nicotinamide phosphoribosyltransferase (NAMPT)/pre-B cell colony (PBEF)/ visfatin linking obesity and inflammation in humans. Diabetologia 2011; 54: 1200-11.

60. Patel L, Buckels AC, Kinghorn IJ, Murdock PR, Holbrook JD, Plumpton C. et al. Resistin is expressed in human macrophages and directly regulated by PPAR gamma activators. Biochem Biophys Res Commun 2003; 300: 472-6.

61. Patel L, Buckels AC, Kinghorn IJ, Murdock PR, Holbrook JD, Plumpton C. et al. Resistin is expressed in human macrophages and directly regulated by PPAR gamma activators. Biochem Biophys Res Commun 2003; 300: 472-6.

62. Nieva-Vazquez A, Pérez-Fuentes R, Torres-Rasgado E, López-López JG, Romero JR. Serum resistin levels are associated with adiposity and insulin sensitivity in obese Hispanic subjects. Metab Syndr Relat Disord 2014; 12: 143-8.

63. Savage DB, Sewter CP, Klenk ES, Segal DG, Vidal-Puig A, Considine RV. et al. Resistin / Fizz3 expression in relation to obesity and peroxisome proliferator-activated receptor-gamma action in humans. Diabetes 2001; 50: 2199-202.

64. Sentinelli F, Romeo S, Arca M, Filippi E, Leonetti F, Banchieri M. et al. Human resistin gene, obesity, and type 2 diabetes: mutation analysis and population study. Diabetes 2002; 51: 860-2.

65. Azuma K, Oguchi S, Matsubara Y, Mamizuka T, Murata M, Kikuchi H. et al. Novel resistin promoter polymorphisms: association with serum resistin level in Japanese obese individuals. Horm Metab Res 2004; 36: $564-70$.

66. Ortega L, Riestra P, Navarro P, Gavela-Perez T, Soriano-Guillen L, Garces C. Resistin levels are related to fat mass, but not to body mass index in children. Peptides 2013; 49: 49-52.

67. Steppan CM, Bailey ST, Bhat S, Brown EJ, Banerjee RR, Wright CM. et al. The hormone resistin links obesity to diabetes. Nature 2001; 409: 307-12.

68. Banerjee RR, Rangwala SM, Shapiro JS, Rich AS, Rhoades B, Qi Y. et al. Regulation of fasted blood glucose by resistin. Science 2004; 303: $1195-8$

69. Hivert MF, Sullivan LM, Fox CS, Nathan DM, D'Agostino RB, Sr., Wilson PW. et al. Associations of adiponectin, resistin, and tumor necrosis factor-alpha with insulin resistance. J Clin Endocrinol Metab 2008; 93: 3165-72.
70. Geyikli I, Keskin M, Kor Y, Akan M. Increased resistin serum concentrations in patientswith type 1 diabetes mellitus. J Clin Res Pediatr Endocrinol 2013; 5: 189-93.

71. Osawa H, Yamada K, Onuma H, Murakami A, Ochi M, Kawata H. et al. The $\mathrm{G} / \mathrm{G}$ genotype of a resistin single-nucleotide polymorphism at -420 increases type 2 diabetes mellitus susceptibility by inducing promoter activity through specific binding of Sp1/3. Am J Hum Genet 2004; 75: 678-86.

72. Kaser S, Kaser A, Sandhofer A, Ebenbichler CF, Tilg H, Patsch JR. Resistin messenger-RNA expression is increased by proinflammatory cytokines in vitro. Biochem Biophys Res Commun 2003; 309: 286-90.

73. 73 gawa-Yamauchi M, Bovenkerk JE, Juliar BE, Watson W, Kerr K, Jones R. et al. Serum resistin (FIZZ3) protein is increased in obese humans. J Clin Endocrinol Metab 2003; 88: 5452-5.

74. Yang Q, Graham TE, Mody N, Preitner F, Peroni OD, Zabolotny JM. et al. Serum retinol binding protein 4 contributes to insulin resistance in obesity and type 2 diabetes. Nature 2005; 436: 356-62.

75. Graham TE, Yang Q, Bluher M, Hammarstedt A, Ciaraldi TP, Henry RR. et al. Retinol-binding protein 4 and insulin resistance in lean, obese, and diabetic subjects. N Engl J Med 2006; 354: 2552-63.

76. Janke J, Engeli S, Boschmann M, Adams F, Bohnke J, Luft FC. et al. Retinol-binding protein 4 in human obesity. Diabetes 2006; 55 : 2805-10.

77. Yao-Borengasser A, Varma V, Bodles AM, Rasouli N, Phanavanh $B$, Lee MJ. et al. Retinol binding protein 4 expression in humans: relationship to insulin resistance, inflammation, and response to pioglitazone. J Clin Endocrinol Metab 2007; 92: 2590-7.

78. Ulgen F, Herder C, Kuhn MC, Willenberg HS, Schott M, Scherbaum WA. et al. Association of serum levels of retinol-binding protein 4 with male sex but not with insulin resistance in obese patients. Arch Physiol Biochem 2010; 116: 57-62.

79. Bobbert T, Raila J, Schwarz F, Mai K, Henze A, Pfeiffer AF. et al. Relation between retinol, retinol-binding protein 4 , transthyretin and carotid intima media thickness. Atherosclerosis 2010; 213: 549 51.

80. Sasaki M, Otani T, Kawakami M, Ishikawa SE. Elevation of plasma retinol-binding protein 4 and reduction of plasma adiponectin in subjects with cerebral infarction. Metabolism 2010; 59: 527-32.

81. Aeberli I, Biebinger R, Lehmann R, L'allemand D, Spinas GA, Zimmermann MB. Serum retinol-binding protein 4 concentration and its ratio to serum retinol are associated with obesity and metabolic syndrome components in children. J Clin Endocrinol Metab 2007; 92: 4359-65.

82. Reinehr T, Stoffel-Wagner B, Roth CL. Retinol-binding protein 4 and its relation to insulin resistance in obese children before and after weight loss. J Clin Endocrinol Metab 2008; 93: 2287-93.

83. Yeste D, Vendrell J, Tomasini R, Gallart LL, Clemente M, Simon I. et al. Retinol-binding protein 4 levels in obese children and adolescents with glucose intolerance. Horm Res Paediatr 2010; 73: 335-40.

84. Qi Q, Yu Z, Ye X, Zhao F, Huang P, Hu FB. et al. Elevated retinolbinding protein 4 levels are associated with metabolic syndrome in Chinese people. J Clin Endocrinol Metab 2007; 92: 4827-34.

85. Lim S, Yoon JW, Choi SH, Park YJ, Lee JJ, Park JH. et al. Combined impact of adiponectin and retinol-binding protein 4 on metabolic syndrome in elderly people: the Korean Longitudinal Study on Health and Aging. Obesity (Silver Spring) 2010; 18: 826-32.

86. Wu Y, Li H, Loos RJ, Qi Q, Hu FB, Liu Y. et al. RBP4 variants are significantly associated with plasma RBP4 levels and hypertriglyceridemia risk in Chinese Hans. J Lipid Res 2009; 50: 1479-86.

87. Haider DG, Schindler K, Prager G, Bohdjalian A, Luger A, Wolzt M. et al. Serum retinol-binding protein 4 is reduced after weight loss in morbidly obese subjects. J Clin Endocrinol Metab 2007; 92: 1168-71.

88. Balagopal P, Graham TE, Kahn BB, Altomare A, Funanage V, George D. Reduction of elevated serum retinol binding protein in obese children by lifestyle intervention: association with subclinical inflammation. J Clin Endocrinol Metab 2007; 92: 1971-4. 
89. Promintzer $M$, Krebs $M$, Todoric J, Luger A, Bischof MG, Nowotny P. et al. Insulin resistance is unrelated to circulating retinol binding protein and protein C inhibitor. J Clin Endocrinol Metab 2007; 92: 4306-12.

90. von EM, Lepper PM, Liu D, Lang K, Baumann M, Nawroth PP. et al. Retinol-binding protein 4 is associated with components of the metabolic syndrome, but not with insulin resistance, in men with type 2 diabetes or coronary artery disease. Diabetologia 2007; 50: 1930-7.

91. Ribel-Madsen R, Friedrichsen M, Vaag A, Poulsen P. Retinol-binding protein 4 in twins: regulatory mechanisms and impact of circulating and tissue expression levels on insulin secretion and action. Diabetes 2009; 58: 54-60.

92. Chavez AO, Coletta DK, Kamath S, Cromack DT, Monroy A, Folli F. et al. Retinol-binding protein 4 is associated with impaired glucose tolerance but not with whole body or hepatic insulin resistance in Mexican Americans. Am J Physiol Endocrinol Metab 2009; 296: E75864.

93. Maury E, Brichard SM. Adipokine dysregulation, adipose tissue inflammation and metabolic syndrome. Mol Cell Endocrinol 2010; 314: 1-16.

94. Kotnik P, Keuper M, Wabitsch M, Fischer-Posovszky P. Interleukin1 beta downregulates RBP4 secretion in human adipocytes. PLoS One 2013; 8: e57796.

95. Sell H, Eckel J. Regulation of retinol binding protein 4 production in primary human adipocytes by adiponectin, troglitazone and TNFalpha. Diabetologia 2007; 50: 2221-3.

96. Cho YM, Youn BS, Lee H, Lee N, Min SS, Kwak SH. et al. Plasma retinol-binding protein-4 concentrations are elevated in human subjects with impaired glucose tolerance and type 2 diabetes. Diabetes Care 2006; 29: 2457-61.

97. Jia W, Wu H, Bao Y, Wang C, Lu J, Zhu J. et al. Association of serum retinol-binding protein 4 and visceral adiposity in Chinese subjects with and without type 2 diabetes. J Clin Endocrinol Metab 2007; 92: 3224-9.

98. Kim IK, Lee HJ, Kang JH, Song J. Relationship of serum retinolbinding protein 4 with weight status and lipid profile among Korean children and adults. Eur J Clin Nutr 2011; 65: 226-33.

99. Tan BK, Chen J, Lehnert H, Kennedy R, Randeva HS. Raised serum, adipocyte, and adipose tissue retinol-binding protein 4 in overweight women with polycystic ovary syndrome: effects of gonadal and adrenal steroids. J Clin Endocrinol Metab 2007; 92: 2764-72.
100. Kos K, Wong S, Tan B, Kerrigan D, Randeva H, Pinkney J. et al. Human RBP4 adipose tissue expression is gender specific and influenced by leptin. Clin Endocrinol (Oxf) 2011; 74: 197-205.

101. Stefan N, Hennige AM, Staiger H, Machann J, Schick F, Schleicher E. et al. High circulating retinol-binding protein 4 is associated with elevated liver fat but not with total, subcutaneous, visceral, or intramyocellular fat in humans. Diabetes Care 2007; 30: 1173-8.

102. Takebayashi K, Suetsugu M, Wakabayashi S, Aso Y, Inukai T. Retinol binding protein- 4 levels and clinical features of type 2 diabetes patients. J Clin Endocrinol Metab 2007; 92: 2712-9.

103. Nishizawa H, Shimomura I, Kishida K, Maeda N, Kuriyama H, Nagaretani $\mathrm{H}$. et al. Androgens decrease plasma adiponectin, an insulin-sensitizing adipocyte-derived protein. Diabetes 2002; 51: 2734-41.

104. Wabitsch M, Brenner RE, Melzner I, Braun M, Moller P, Heinze E. et al. Characterization of a human preadipocyte cell strain with high capacity for adipose differentiation. Int J Obes Relat Metab Disord 2001; 25: 8-15.

105. Goralski KB, McCarthy TC, Hanniman EA, Zabel BA, Butcher EC, Parlee $\mathrm{SD}$. et al. Chemerin, a novel adipokine that regulates adipogenesis and adipocyte metabolism. J Biol Chem 2007; 282: 28175-88.

106. Shin HY, Lee DC, Chu SH, Jeon JY, Lee MK, Im JA. et al. Chemerin levels are positively correlated with abdominal visceral fat accumulation. Clin Endocrinol (Oxf.) 2012; 77: 47-50.

107. Reyman M, Verrijn Stuart AA, van Summeren M, Rakhshandehroo M, Nuboer R, de Boer FK. et al. Vitamin D deficiency in childhood obesity is associated with high levels of circulating inflammatory mediators, and low insulin sensitivity. Int J Obes (Lond) 2014; 38: 46-52.

108. Chu SH, Lee MK, Ahn KY, Im JA, Park MS, Lee DC. et al. Chemerin and adiponectin contribute reciprocally to metabolic syndrome. PLoS One 2012; 7: e34710.

109. Landgraf K, Friebe D, Ullrich T, Kratzsch J, Dittrich K, Herberth $G$. et al. Chemerin as a mediator between obesity and vascular inflammation in children. J Clin Endocrinol Metab 2012; 97: E556-64. 